\title{
ОЗНАКИ БАРОКО В ХУДОЖНЬОМУ ПРОСТОРІ ТА СТИЛІСТИЧНІЙ ПЛОЩИНІ П'ЄСИ В. ШЕКСПІРА «БУРЯ»
}

Михальченко Т. В. Ознаки бароко у художньому просторі та стилістичній площині п’єси В. Шекспіра «Буря».

У статті досліджено вплив барокової естетики на драматургію В. Шекспіра. У п’єсі «Буря» застосовано бароковий інструментарій на рівні вибору сюжету, драматичних емоцій і концепції героїв. Використання прийомів бароко розглядається як засіб вільного віддзеркалення мінливості та динамічності життя, суперечностей та антиномій епохи. Бароко зароджується в надрах пізнього Відродження і відображає світ в усій своїй складності, багатогранності виявів, безмежності й мінливості. П'єса «Буря» маніфестує різні засоби відтворення й перетворення дійсності, у якій поєдналися ілюзія і реальність, прекрасне і жахливе, жага щасливого життя і трагізм. Художній простір та стилістика п'єси відтворюють суперечливість світу і самого буття, що в уявленні автора $\epsilon$ суцільним лабіринтом, де особистість зіштовхується з різними силами й постійно випробовується на духовну стійкість.

() Т. В. Михальченко, 2016. 
Ключові слова: ілюзорність, видовище, барокова сценічність, «бути здаватися», «театр у театрі», «ефект дзеркала».

Михальченко Т. В. Признаки барокко в художественном пространстве и стилистической плоскости пьесы В. Шекспира «Буря».

В статье осуществлена попытка исследовать влияние барочной эстетики на драматургию В. Шекспира. В пьесе «Буря» применен барочный инструментарий на уровне сюжета, драматических эмоций и концепции героев. Использование приемов барокко рассматривается как средство свободного отражения динамичности жизни, противоречий и антиномий эпохи. Барокко рождается в недрах позднего Возрождения и отражает мир во всей его сложности, многогранности проявлений, безграничности и переменчивости. Пьеса «Буря» сочетает в себе разные средства воссоздания и превращения действительности, в ней объединены иллюзия и реальность, прекрасное и ужасное, жажда счастливой жизни и трагизм. Художественное пространство и стилистика пьесы воссоздают противоречивость мира, который в представлении автора является сплошным лабиринтом, где личность сталкивается с разными силами и постоянно испытывается на духовную стойкость.

Ключевые слова: иллюзорность, зрелище, барочная сценичность, «быть казаться», «театр в театре», «эффект зеркала».

Mikhalchenko T. V. Signs of the Baroque the art space and stylistic plane of William Shakespeare's "the Tempest"

The article presents an attempt to explore the influence of Baroque aesthetics in the drama of Shakespeare. In the play "the Tempest" is applied to the Baroque instrumentation at the level of plot, drama and emotion of the concept of heroes. Using the techniques of the Baroque is seen as a means of free reflection of the dynamism of life, of contradictions and antinomies of the era. Shakespeare was acutely perceived the contradictions of his time. Hence the dynamics and drama of his works, the richness of struggle, clashes, conflicts. A deep comprehension of the trends of the time and led to the dynamic attitude of Shakespeare to the present, along with the growth of the skill determines the evolution of his work. Baroque is born in the depths of the late Renaissance and reflects the world in all its complexity, the multiplicity of the manifestations of infinity and change. Play "the Tempest" combines different means of creating and transforming reality, it combines illusion and reality, beauty and horror, the thirst for a happy life and tragedy. Art space and style pieces recreate the inconsistency of the world, which in the view of the author is a solid maze, where the individual is faced with different powers and is constantly being tested for spiritual vitality

Key words: illusiveness, spectacle, baroque performance, "to be - to seem", "play within a play", "mirror effect".

\section{Протягом багатьох століть особистість і творчість В. Шекспіра} привертають увагу багатьох учених, передовсім літературознавців, у результаті чого з'явилося безліч міфів i припущень, іноді діаметрально протилежних. Однак причетність драматурга до С Т. В. Михальченко, 2016. 
гуманістичної культури Англії $\epsilon$ незаперечною: його творчість виражає єдину ментальність єлизаветинської епохи. Вивченням творчості В. Шекспіра займались зарубіжні й вітчизняні науковці (К. Дж. Арган, М. Барг, Е. Берджес, О. Анікст, Ю. Кагарліцький, О. Смирнов, Л. Пінський, Ю. Шведов та ін.). Проте особливості творів «романтичного періоду» не стали предметом грунтовного аналізу, що, власне, зумовлює актуальність запропонованої статті, метою якої $є$ дослідження художнього світу та стилю п’єси В. Шекспіра «Буря», що суттєво відрізняється від інших творів драматурга.

Розглядаючи творчий доробок $\mathrm{B}$. Шекспіра, учені дійшли висновку, що жанрові преференції драматурга точно віддзеркалюють гуманістичні настрої англійського Відродження. Так, для першого етапу творчості (1590-1600рр.) характерне оптимістичне світовідчуття, віра в перемогу доброго й вічного. У ці роки написані найбільш життєрадісні комедії Шекспіра і хроніки, у яких проявився інтерес драматурга до національної історії та перипетій англійського державотворення. Другий, трагічний, період (1601-1608 pp.) відзначився кризою гуманістичних ідей та загальною картиною злиденності народу, що послужило основою для створення чудових трагедій і комедій, які мають глибоко драматичний характер і межують 3 трагедіями. У третій період (1609-1613 рр.) відбувається послаблення трагізму, яке дослідники його творчості пояснюють примиренням 3 дійсністю і навіть втомою драматурга [4, с. 94]. П'єсам цього періоду Шекспір надав філософського характеру і відтінку повчальної притчі («Перікл», «Цимбелін», «Зимова казка», «Буря»).

На сучасному етапі розвитку науки саме пізні твори В. Шекспіра викликають зацікавлення науковців, що подекуди висловлюють думку про неналежність їх до жодного естетичного коду, ідентифікованого в Англії. «Шекспір належить до художників, які не вкладаються в межі звичних понять. У нього свої універсальні мірки, але і він, підносячись над стилями своєї епохи, проте, використовував їх у своїй творчості, перетворюючи їх, як тільки він один умів це зробити» [3, с. 15]. 
Романтичні драми, написані в період із 1608 по 1612 роки, можуть бути розглянуті як казкові післямови до трагічних шекспірівських сюжетів, де в основу покладена трагічна ситуація, однак у розв'язці реальність перетворюється утопічним зором, що обіцяє щастя.

Звернення драматурга до нового для себе жанру, на думку А. Анікста, пояснюється модою придворного театру на п'єси-маски. Розвиток відповідного жанру в англійській драмі був підготовлений, 3 одного боку, напругою в суспільстві, викликаною наступом пуританської реакції, що потребувало певної розрядки. 3 іншого, правляча верхівка віддавала перевагу театру багатобарвному та розважальному, який викликав би яскраві враження, але не спонукав би до серйозних роздумів. «При дворі Джеймза полюбили п’єси-маски - пишні вистави без драматичної фабули, що радували слух поезією i музикою, а погляд - барвистими костюмами i живописними декораціями» [1, с. 292].

П’єса «Буря» належить до жанру романтичної драми, де використовуються деякі елементи жанру маски, збережений драматизм дії, а сюжет наповнений неймовірними пригодами, надмірним злодійством i дивним позбавленням від біди. Тут переплетені всі трагічні мотиви: підступність, злодійство, узурпація трону і свободи, але все це - до початку дії. На сцені ж лиходії - у руках мудрого мага і чарівника Просперо, який був колись герцогом Мілана, а зараз він - обиватель безлюдного острова, де, окрім нього, його доньки i чарівних істот, ніхто не живе. Його магічна сила викликала бурю, що прибила до острова корабель із кривдниками. I тепер від нього залежить їхня подальша доля: страта чи помилування.

Тривалість дії в п’єсах В. Шекспіра була різною. У «Зимовій казці» сюжет охоплює 16 років життя героїв, а в «Бурі»-усі події розгортаються протягом однієї доби. Місцем дії $є$ скелястий, дикий острів, проте картини, змальовані у п'єсі, таять чимало дивного і фантастичного. В основу твору покладено бароковий театральний принцип, який має своєрідний прихований механізм дії. Наприклад, бароковий живопис 
акцентує щонайменші переливи світла і тіні, добиваючись контрастного, багатовимірного простору. Театр бароко має свої важелі дії: «...він чарує глядача грою інколи просто розважальною, інколи драматичною, але саме ілюзія стає основним принципом мімезису» [7, с. 102].

Естетичний, політичний і релігійний світ пізніх п’єс В. Шекспіра схожий за своєю структурою 3 бароковою ідеєю, згідно 3 якою він двоїстий, оманливий, у ньому немає нічого неможливого: бачення, мрія, пророчий сон стають реальними. Надприродне в театрі Шекспіра, починаючи 3 бурлескних відьм у «Макбеті» і закінчуючи видіннями Гамлета, від яких холоне душа, спричиняє появу сильних емоцій, являє собою експериментальне поле для дослідження психіки. Доволі часто задля посилення емоційного тла переломи або духовна криза в долі героїв проектуються й на природу («Король Лір»), злочини або розкаяння совісті ввергають героїв в маніакальний стан («Макбет»), занепокоєні душі 3 потойбіччя являються живим, передають їм свої тривоги й одкровення («Гамлет»). Так, у «Бурі» теж наявні два співвідносні пласти - світ реальний і світ сновидінь. Герої існують то там, то тут, виявляючи себе по-різному. Кордоном переходу з одного стану до іншого служить сон, як тільки-но вони засинають - потрапляють в інший світ, з ними трапляються дива, метаморфози. Сновидіння в п’єсі визначає примарність життя і світу, ілюзорність того, що відбувається. Уявлення, типові для бароко, підкреслені словами Просперо:

Вот так, подобно призракам без плоти,

Когда-нибудь растают, словно дым,

И тучами увенчанные горы,

И горделивые дворияь и храмы,

И даже весь - о да, весь шар земной,

И, как от этих бестелесных масок,

От них не сохранится и следа.

Мы созданы из вещества того же,

Что наши сньл. И сном окружена

Вся наша маленькая жизнь [6, с. 558].

(ㄷ Т. В. Михальченко, 2016. 
Сновидіння визначає і побудову тексту: стрімкий початок дії, різкі зміни, що породжують відчуття нереальності, а іноді й абсурдності того, що відбувається. Крім реальності та світу сновидінь, $\epsilon$ ще один дивний, примарній світ, у якому мешкає чарівний дух Аріель, слуга і помічник Просперо. Виконуючи всі накази свого повелителя, він 3'являється перед глядачами то у своїй тілесній подобі, то в подобі морської німфи або гарпії, то, будучи незримим, здійснює магічні дії над персонажами. Завдяки Аріелю глядач розуміє, що світ не одновимірний, він нестійкий, у ньому можливі будь-які перетворення. Аріель може вводити героїв в оману, увергати їх у сон, створювати в їхній уяві будь-які реальні картини. Герої приголомшені й дезорієнтовані, як-от Себастьян:

Теперь и я поверю в чудеса:

В единорогов, в иарственную птииу,

Что фениксом зовется и живет

В Аравии... [6, с. 547].

Матеріальний і чарівний світи виявляються взаємопроникними. Художній простір п'єси вибудовано по-новому. Якщо у творах епохи Відродження простір лінійний i одновимірний, явища реальності стабільні й незмінні, то тут все нестійке, хитке, немає симетрії і пропорцій. Для розширення просторових лімітів і створення барокової картини світу драматург удається до прийому «театру в театрі», що знаходить віддзеркалення і в інших п'єсах, наприклад, «Мишоловка» в «Гамлеті». А. Вуліс називає це феноменом дзеркала, який, як дзеркальне відображення, відтворює частину історії [2, с. 130]. У «Бурі» вставна п'єса-маска, персонажами якої виступають римські богині Юнона, Ірида, Церера, відображає майбутні події, пов'язані з одруженням Фердинанда i Міранди. Проте фінал п’єси неоднозначний. Відчуття щастя, ясності і безтурботності поступається місцем сумніву. Глядач не упевнений, що всі сподівання Просперо будуть утілені в реальність. Автор залишає своїх героїв на півдорозі до щастя. Відкритість форми також є невід'ємною ознакою барокової

(C) Т. В. Михальченко, 2016. 
поетики. Часто твір являє собою фрагмент видимої реальності, випадково схоплений творцем. Деформуючи в такий спосіб простір, граючи 3 ним, В. Шекспір намагається відобразити динамічний принцип бароко, есенцію самого життя, його мінливість.

Морально-етична проблематика п'єси знаходить форму за допомогою вживання різних стилістичних прийомів. Ренесансна гармонія, стабільність і ясність зображення в «Бурі» відходять на задній план, поступаючись місцем бароковим дисонансам, невловимості і безладності світу. Насамперед «Буря» є єдиною п’єсою, де метафора виявляється настільки явно, що винесена навіть у назву. Метафоричність та образність заголовка створює ефект перелому в житті героїв, коли злодійство й обман викриті, за допомогою магічної сили мають бути відновлені гармонія i справедливість. Подібні порівняння почуттів, дій i явищ дійсності з несамовитими силами природи суголосні бароковій інтерпретації світу. Барокове мистецтво схильне змальовувати реалії через символи. Наприклад, вода, хмара, вогонь символізують швидкоплинність життя, а буря, блискавки, затишия, веселка - мінливість відчуттів і явищ. У цьому сенсі Шекспір близький до тих барокових авторів, що сприймають світ у його образній оболонці. П'єса рясніє метафорами (колесница времени, снег целомудрия, жар страстей, ветерок так нежно вздыхает і т. ін.). Поряд із ренесансними епітетами і порівняннями, орієнтованими на зорові враження, Шекспір використовує і консейти, які стануть однією 3 улюблених стилістичних фігур літератури бароко. Це складна метафора, звернена до активної уяви, «комбінація образів, не подібних один до одного, або віднайдення прихованої подібності у предметах, що здаються неподібними» [5, с. 242]. Наприклад: Будь сдержан: $u$ великие обеть / В огне страстей сгорают, как солома», або «Смотрите, он заводит часы своего остроумия, сейчас они начнут бить. У тексті п'єси натрапляємо й на антитези, якими активно послуговуються митці задля висвітлення контрастів реальності: Порой забава причиняет боль / Порою тяжкий труд дает отраду» [6, с. 532]. 
Аби краще відтінити внутрішній світ героїв, драматург удається до змішування стилів, використовує знижену лексику, просторіччя:

Боцман: Чума задави этих горлодеров! Они заглушают и бурю, и капитанский свисток! Опять вы тут? Чего вам надо?

Себастьян: Язва тебе в глотку, проклятый горлан! Нечестивый, злобный пес - вот ты кто!...

Антонио: Подлый трус! Мы меньше боимся утонуть, чем ты, грязный ублюдок, наглая ты скотина! [6, с. 479].

Подекуди персонажі говорять піднесеним, поетичним стилем:

Миранда: Так меня Вы любите?

Фердинанд: И небеса, и землю

Зову в свидетели моей любви!

Коль правду говорю я - пусть они

Мое признанье счастьем увенчают;

А если лгу - пусть в беды обратят

Все радости, что мне судьба сулила!

Бескрайне, безгранично, беспредельно

Тебя люблю, боготворю и чту! [6, с. 536].

Літературі Відродження загалом «ще чужа тема людської самоти.

Тема глибокого розладу героя зі світом і наростаючого усвідомлення своєї самоти виникає під кінець епохи Відродження. У цій темі виражається криза гуманістичної думки, саме 3 неї починається світовідчуття бароко» [4, с. 68]. Ставлення Просперо до людей і нового світу пройняте внутрішнім сум'яттям, він самотній, не вірить людям. Випробовуючи Фердинанда, намагається зрозуміти його внутрішню суть. Просперо переконався на гіркому досвіді, що людина може прикидатися, i грань між людиною i маскою, яку вона одягає i зживається з нею, дуже тонка. Звідси, відповідно, В. Шекспір впритул підходить до барокової проблеми бути - здаватися. Світ, змальований у «Бурі», не такий, яким здається: відбувається спотворення всіх його форм, починаючи зі звичайного ігрового вдавання i закінчуючи найглибшим лицемірством, це світ, що приховує правду.

(C) Т. В. Михальченко, 2016. 
Завдяки чарівним силам Просперо відновлює справедливість, його кривдники усвідомлюють свою провину. Щоправда, епілог руйнує впевненість у тому, що гармонію відновлено. Визнання героя в тому, що він - слабка, грішна людина, доля якої - благання й душевне примирення, змушують глядача в усьому сумніватися. В. Шекспір розставляє акценти по-іншому. Для людини Відродження все було можливо, для людини бароко - усе однаково сумнівно й ілюзорно. Відтак, у фіналі п’єси домінують рефлексія та песимізм - риси, притаманні бароковим творам.

Дослідивши художній простір п’єси «Буря», ми виявили в ньому цілу систему барокових засобів відображення дійсності. Насамперед у п'єсі втілена барокова ідея про ілюзорність та облудність світу і людини, яка приховує свою справжню суть, свої вади під маскою. Переплітаючи природне 3 дивним, автор деформує простір, засвідчуючи тим самим дисгармонію й хаос, що панують у світі. Метаморфози, які відбуваються 3 героями, демонструють: Шекспір сприймає особистість не як гармонійну, а як складну і суперечливу.

Залучаючи міфологічний арсенал старовини (чарівні духи, німфи, богині), драматург намагається не стільки орнаментально прикрасити п’єсу, скільки довести, що в довкіллі панують невідомі сили, дія яких непередбачувана. Ця таємнича атмосфера стає предметом видовища, спектаклю й підтверджує мінливість і нестійкість світу. Естетичними домінантами стилю «Бурі» стають метафори, гра, ілюзія, сон, мінливі форми, що є основами барокової поетики.

Отже, твір В. Шекспіра $є$ не лише розважальною, романтичною п'єсою-маскою, але й отримує нове прочитання і нове смислове навантаження завдяки його бароковій природі.

\section{Література}

1. Аникст А. А. Шекспир / А. А. Аникст. - М. : Молодая гвардия, 1964. - 495 с.

2. Вулис А. 3. Литературные зеркала / А. 3. Вулис. - М. : Советский писатель, 1991. $-480 \mathrm{c}$.

3. Горбунов А. Н. Драматургия младших современников Шекспира / А. Н. Горбунов // Горбунов А. Н. Младшие современники Шекспира. - М. : Изд-во МГУ, 1986. - С. 3-26. 
4. Пинский Л. Е. Магистральный сюжет / Л. Е. Пинский. - М. : Советский писатель, 1989. - 416 с.

5. Шалагінов Б. Б. Зарубіжна література від античності до початку XIX сторіччя / Б. Б. Шалагінов. - К. : Вид-во «Києво-Могилянська академія», 2007. - 360 с.

6. Шекспир У. Комедии : Пьесы ; [пер. с англ. М. Зенкевича, М. Донского, П. Мелковой, Т. Щепкиной-Куперник] / У. Шекспир. - М. : Изд-во ЭКСМО-пресс, 1999. - $736 \mathrm{c}$.

7. Levillain H. Qu'est-ce que le Baroque? / H. Levillain. - Paris : Klincksieck, 2003. - 200 p. Стаття надійила до редакиії 29.11.2016 p. 